\title{
Janela para o mundo: a TV no cárcere feminino em Belém
}

\section{Window to the world: the case of female prison on TV in Belém}

Nara Cristina Moura Pessoa - Especialista em Gestão penitenciária pela FAP (2012); servidora do Tribunal de Justiça do Pará (TJPA), Belém-PA. E-mail: narapessoa1@ hotmail.com

Wilson José Barp - Doutor em Ciências Sociais pela Universidade Estadual de Campinas (1997); professor associado da Universidade Federal do Pará, Belém-PA. E-mail: wbarp@ uol.com.br

Fernanda Valli Nummer - Doutora em Antropologia Social pela Universidade Federal do Rio Grande do Sul (2010); pesquisadora e professora da Universidade Federal do Pará, Belém-PA. E-mail: fernandanummer@gmail.com

\section{Resumo}

A pesquisa que originou este trabalho buscou compreender o papel da televisão no processo de sociabilidade das mulheres em situação de cárcere, que cumprem pena em regime semiaberto no Centro de Reeducação Feminino do Estado do Pará (CRF). A pesquisa apresentase como qualitativa, na qual se utilizou as técnicas da observação simples e entrevistas informais, contando com a participação de oito interlocutoras. Os programas mais assistidos pelas mulheres presas são os jornais policiais das emissoras locais, pela preocupação com a família, que geralmente está envolvida no tráfico; e um programa que mostra as festas noturnas que muitas delas frequentavam antes da prisão, oportunidades que elas têm de ver seus familiares, amigos e ex-companheiros. Outro programa muito assistido é uma novela da rede Globo, porque traz o discurso da homossexualidade, um aspecto comum no presídio feminino. Assim, a televisão é considerada pelas internas um equipamento essencial durante o cumprimento da pena, porque as mantêm informadas dos fatos ocorridos fora da prisão, o que nos faz repensar a prisão como uma instituição fechada, caracterizada pela barreira de contato com o mundo exterior.

\section{Palavras-chave}

Cárcere. Sociabilidade. Mídia.

\begin{abstract}
This research sought to understand the role of television in women sociability process that the prison situation serving time in semi-open regime in Reeducation Center Female of the State of Pará (CRF). The research is presented as qualitative and used the techniques of informal interview and the simple observation, and had the participation of eight interlocutors. Most assistors programs for women in prison are cops newspapers, the concern with the family that usually is involved in trafficking; and Para Show program, because it shows the night parties they attended before the arrest, they have opportunity to see family, friends and former colleagues ; other program much assisted is the novel In Family, Globe network, because it brings the discourse of homosexuality, common reality in the women's prison. Thus, television is considered by internal an essential tool for serving the sentence because keeps informed of events outside the prison, which makes us rethink the prison as a closed institution born characterized by contact barrier to the world.
\end{abstract}

\section{Keywords}

Prison. Sociability. Media. 


\section{INTRODUÇÃO}

Diante do fato de que as pessoas em situação de cárcere têm o direito de acesso aos meios de comunicação nas prisões para se manterem informadas, a pesquisa que deu origem a este trabalho buscou compreender a influência dos conteúdos veiculados na televisão no processo de sociabilidade das internas que cumprem pena em regime semiaberto no Centro de Reeducação Feminino do Pará (CRF).

A definição do tema se deu em virtude da experiência profissional da primeira autora na área da comunicação social, no Sistema Penitenciário do Pará (Susipe), por um período de aproximadamente quatro anos. Durante este tempo observouse que assistir TV fazia parte da rotina das presidiárias, visto que a legislação garante este direito, bem como pela escassez de estudos abordando essa temática.

Diante desse contexto, a pesquisa foi realizada no Centro de Reeducação Feminino (CRF), única unidade prisional exclusivamente feminina das 42 unidades prisionais existentes no estado do Pará. O CRF está localizado no município de Ananindeua, na Região Metropolitana de Belém (RMB). A unidade mantém aproximadamente 600 mulheres $^{1}$ sob sua custódia. Desse total, 420 cumprem pena em regime fechado ${ }^{2}$ e 120 no regime semiaberto.

A pesquisa também foi direcionada à diretora do CRF, porque precisávamos saber qual a percepção da gestão da unidade em relação à TV no processo de sociabilidade das internas; a dois servidores penitenciários; e a oito mulheres que cumprem pena em regime semiaberto e não trabalham ou estudam fora da prisão, visto que, se elas saíssem para trabalhar, não seria possível realizar a pesquisa, pois aquelas que exercem atividades fora saem às seis da manhã e retornam às 17 horas, horário em que a autora não estaria mais no CRF, pois este é o momento em que elas se recolhem para as celas.

As internas do regime semiaberto foram selecionadas por orientação da equipe de segurança, visto que durante o dia elas podem circular em uma área livre próxima ao bloco específico para alocar as detentas neste regime, o que não ocorre no caso das internas em regime fechado. Logo, se escolhêssemos estas últimas, dependeríamos dos agentes prisionais para conduzi-las, o que não ocorreu com o segmento selecionado para participar da pesquisa.

1 Número verificado no relatório "SUSIPE em Números", referente ao mês de outubro de 2014, disponível em: < http://www.susipe.pa.gov.br/>.

2 As internas sentenciadas cumprem sua pena em regime fechado ou semiaberto. $\mathrm{O}$ regime fechado requer o cumprimento em presídios de segurança máxima ou média. Já o semiaberto, pode ser uma progressão do regime fechado, e deve ser cumprido em colônia agrícola, industrial ou instituição similar. 
Os instrumentos de coleta de dados foram adotados de acordo com a perspectiva de Lakatos e Marconi (2011) e Gil (2012), que consideram as técnicas da entrevista informal e da observação simples mais adequadas para se compreender as representações que os entrevistados dão às experiências e fatos de sua vida cotidiana. Para preservar a identidade das oito mulheres que aceitaram participar como interlocutoras da pesquisa, solicitamos que se identificassem pelo nome de uma flor, ficando assim autodenominadas: Jasmim, Rosa Vermelha, Girassol, Lirio, Amor Crescido, Margarida, Alecrim e Camélia.

Para algumas, o nome da flor foi escolhido por ter um significado especial em suas vidas, como o caso de Jasmim, que justificou: "Minha avó usava essa flor no cabelo, por isso que gosto desse nome". Para Amor Crescido, o motivo foi: "gosto dessa flor porque para mim representa maturidade, algo bom". Rosa Vermelha escolheu este codinome, alegando que: "adoro essa flor, ela representa o amor. Já sofri tanto por amor"; e Alecrim preferiu ser chamada dessa forma porque: "é um nome que representa alegria".

\section{A TV NO CONTEXTO DA PRISÃO}

A sociedade atual é fortemente marcada pela presença dos meios de comunicação - rádio, televisão, internet, redes sociais - que assumem um papel "estruturante" no cotidiano das pessoas. Esses meios fazem a mediação das relações sociais, influenciam o pensamento e os costumes, por meio da difusão de valores culturais. A televisão ainda é um dos veículos de maior alcance social, sendo utilizada em múltiplos contextos, entre eles a prisão. Para Thompson (2012, p. 72), “O alcance da televisão em sua expansão global, torna-se cada vez mais acessível aos indivíduos em todo o mundo".

Canclini (2002) define a mídia ou meios de comunicação de massa como canais que registram e difundem informações. Ao utilizar esses canais, o indivíduo não pertence mais a um país, e sim ao mundo. Ao clicar o controle remoto, o sujeito entra em contato com outras realidades, formando um todo de informações que serão absorvidas. Em virtude da sua importância para os indivíduos, a TV também faz parte do sistema carcerário. Sua presença é legitimada ${ }^{3}$ pela Lei de Execução Penal (LEP), que no artigo 41, inciso XV, determina - O contato com o mundo exterior será por meio de correspondência escrita, da leitura e de outros meios de informação que não comprometam a moral e os bons costumes. O parágrafo

Para aprofundar a leitura sobre a legislação, ver Regras mínimas para Tratamento de Reclusos da Organização das Nações Unidas (ONU) e Regras Mínimas para o Tratamento do Preso (Resolução no 14, de 11 de novembro de 1994). 
único deste mesmo artigo afirma que esses meios poderão ser suspensos ou restringidos mediante ato motivado do diretor da unidade prisional. Isto é, se os meios disponibilizados no cárcere estiverem interferindo de alguma forma na boa convivência entre pessoas privadas de liberdade, o diretor poderá tomar as providências cabíveis e até mesmo regulamentar o uso do eqipamento.

A partir dessa garantia, o CRF possui, ao todo, cerca de 90 aparelhos de televisão, ${ }^{4}$ distribuídos nas várias celas que abrigam detentas dos regimes fechado e semiaberto. $\mathrm{O}$ acesso aos conteúdos veiculados é livre, bem como os horários, ou seja, a TV pode ser ligada a qualquer hora do dia ou da noite, sem restrições. Direcionando a pesquisa para o regime semiaberto, identificou-se que há cerca de trinta televisores nas celas desse regime.

Para instalar um aparelho de TV no cárcere, este deve ser de 14 polegadas e levado pelos familiares das internas ou comprada ${ }^{5}$ daquelas que obtiveram a liberdade. Quando um televisor chega ao CRF é expedido um documento atestando quem é a proprietária, depois de passar por uma revista para que a equipe de segurança certifique-se de que não há objetos ilícitos dentro do aparelho. Apesar do direito previsto em lei, o uso da TV no cárcere ainda não é regulamentado pelo Sistema Penitenciário do Estado do Pará (Susipe) ${ }^{6}$ que, mesmo permitindo a entrada do equipamento, não detém de controle formal sobre ele. Uma vez instalada na cela, não são estabelecidas normas de horários para o uso desse equipamento pela gestão e, a partir de então, a TV pode ser ligada a qualquer hora do dia ou da noite.

Durante a pesquisa ficou evidente que a TV é um objeto de troca na prisão. Conforme se observa no depoimento de um agente penitenciário que trabalha há 9 meses no CRF: "Na cadeia, a TV é um bem muito valioso. Uma vez uma interna pediu 50 reais emprestado para outra e a TV foi dada como garantia de pagamento". Ressalta-se, então, que a TV é comercializada junto com outros itens, a fim de obterem dinheiro e garantir um meio de sobrevivência.

Segundo as entrevistadas, tudo na prisão é pago, inclusive o direito de assistir TV. Então, elas precisam encontrar uma forma de ganhar dinheiro, principalmente as internas que não recebem visitas, como é a realidade da maioria.

Informação prestada pela diretora do CRF, em junho de 2014, durante a pesquisa de campo.

O valor da televisão seminova, no momento da pesquisa, variava entre 80 a 120 reais, quando era comprada individualmente. Se fosse adquirida junto com o espaço da cela, saía mais caro, visto que elas só podem ficar juntas quando por um espaço na cela - o que é chamado por elas de "beco".

6 Órgão criado pela Lei no 4.713, de 26 de maio de 1977. Autarquia vinculada à Secretaria de Estado de Segurança Pública, regida pela Lei no 6.688, de 13 de setembro de 2004, e suas alterações, com autonomia administrativa e financeira, dispondo de dotação orçamentária própria, tendo por finalidade a execução penal, efetivando as disposições de sentença ou decisão criminal, custodiando o interno e promovendo a sua reintegração social. 
Caso contrário, elas ficam na dependência de outras mulheres, o que se torna um sofrimento para as detentas. Aquelas que não recebem visitas, de certo modo são humilhadas pelas demais. No cárcere, o fato de não receber visita significa desprestígio (SANTANA, 2012).

Aqui a gente vale o que tem. Qualquer favor tem que pagar. Tudo no CRF é pago, colchão, quarto, cama. Um empanado ${ }^{7}$ com tudo, inclusive televisão é cerca de 200 reais" (Jasmim, 28 anos, condenada por tráfico de drogas; estudou até a $4^{\text {a }}$ série).

Quando saem do regime fechado, na maioria das vezes as internas vão para o semiaberto. De acordo com a referida Lei, essa transição é chamada de progressão da pena. Ao passar para o regime semiaberto, a interna deve comprar um "beco" ou "empanado"; e se não o fizer, ficará pelos corredores do anexo, sem privacidade e dormindo no chão. As internas que vão saindo do regime semiaberto deixam os empanados para uma amiga negociar com as recémchegadas.

Quando cheguei no semiaberto, meu quarto custou 500 reais, com duas televisões. Quando comprei, chamei para morar comigo a moça que foi presa junto comigo, mas ela tem a TV dela e eu tenho a minha. Eu recebo 200 reais do meu marido toda semana para me manter aqui na prisão" (Margarida, 46 anos, acusada pelo crime de tráfico; técnica em administração e contabilidade).

Eu comprei o empanado por cem reais, e veio só com cama, colchão e televisão. Agora divido com mais duas que compraram um espaço no meu beco. Mas eu que mando na TV, as outras só ligam se eu quiser. Eu comprei então é minha" (Girassol, 37 anos, condenada pelos crimes de tráfico e homicídio; estudou até a $6^{\mathrm{a}}$ série).

Nos relatos, percebe-se que a TV valoriza o espaço no cárcere, e junto temse a relação de poder, que advém do dinheiro. Aquelas que podem pagar dispõem de certo "conforto". Pelo que foi observado, a direção do CRF desconhece essa prática comum. O fato de uma interna ocupar um espaço em qualquer cela da prisão deveria ser uma determinação da gestão da unidade, o que, de fato, seria natural, no entanto, para a interna, torna-se um momento de tensão, pois quando ela sabe que vai para o semiaberto, fica apreensiva porque terá que pagar pelas suas acomodações.

\footnotetext{
Também chamado de "beco", consiste em várias camas ou beliches localizados em um determinado espaço da cela, divididos por lençóis. Isso proporciona às internas certa "privacidade". Em um beco ou empanado pode haver uma cama ou várias, dependendo da amizade entre as detentas. Um empanado com televisão, cama, colchão e ventilador custa cerca de 200 reais, e esse valor pode variar de acordo com os itens existentes no local. O empanado sem televisão custa entre 50 e 100 reais.
} 
Foucault (2012) assinala que o poder é uma "prática social”, que está no cotidiano e se estabelece por meio das relações de força entre as pessoas. Foucault (2012), ao analisar a dinâmica do poder, pensa "na sua forma capilar de existir, no ponto em que o poder encontra o nível dos indivíduos, atinge seus corpos vem inserir em seus gestos, suas atitudes, seus discursos, sua aprendizagem, sua vida cotidiana" (FOUCAULT, 2012, p. 215).

A TV é a principal arma que a direção tem. Quando elas estão tentando alguma coisa de errado, a direção avisa: se vocês tentarem alguma coisa eu tiro a TV de vocês." (Agente penitenciária, que trabalha há seis anos no CRF).

No cárcere feminino, o poder se "capilariza" por outras fontes que não a institucional. Em vários momentos, quem determina as regras são as internas consideradas líderes e não a gestão da unidade. Essa questão será retomada mais adiante. Dias (2014) afirma que as regras informais são recursos por meio dos quais se constroem as relações e a determinação dos limites. Essas regras são importantes à medida que proporcionam a manutenção da paz, porque é impossível viver um longo tempo na prisão sem a flexibilização das suas normas. Senão vejamos:

Se tirasse a TV da gente, a gente tacava fogo na cadeia. Na rebelião, a gente quebrou tudo, até que devolveram a TV pra gente (Alecrim, 29 anos, presa por tráfico de drogas; estudou até a $\sigma^{a}$ série)."

Em uma rebelião que teve aqui no $\mathrm{CRF}$, uma das punições foi a retirada da TV. Elas ficaram uma semana sem o aparelho, depois que foi negociado entre a direção e elas. Como punição deve-se tirar o que elas mais gostam" (Agente penitenciária, que trabalha há seis anos no CRF).

Isso nos leva a pensar que "a cadeia não é uma miniatura da sociedade livre, mas um sistema peculiar, cuja característica principal, o poder, autoriza a qualificálo como um sistema de poder" (THOMPSON, 2002, p. 19). Assim, a relação de poder engloba a TV, que acaba sendo usada como objeto de troca no cárcere.

No que tange à importância da TV, as internas a consideram um meio de comunicação extremamente importante durante o cumprimento da pena, como um instrumento de recreação que ocupa o tempo ocioso, distrai e facilita o convívio porque as reúne durante as programações, especialmente os noticiários policiais, conforme se observa nos depoimentos abaixo:

Se não tivesse a TV seria muito ruim, eu teria entrado em depressão. A TV faz o nosso contato direto com o mundo; se não tivesse ela, nós perderíamos a noção do tempo e do mundo. Quando eu estava no regime fechado, ficamos sem televisão quase um mês quando teve a última rebelião (2013). 
Foi muito ruim. A TV só voltou porque as líderes das celas negociaram com a direção e aí foram devolvendo aos poucos" (Margarida, 46 anos, condenada pelo crime de tráfico; técnica em administração e contabilidade).

A TV puxa a cana (cumpre a pena) junto com a gente. Abaixo de Deus é ela que tá com a gente. Quando ficamos sem a TV durante a rebelião do ano passado (2013) foi horrível, não tinha pra onde olhar. Ficou um vazio. Se não tivesse a TV seria um tédio, porque ela distrai a nossa mente; sabemos o que acontece na cidade, assistimos um filme, um jogo" (Lirio, 39 anos, acusada pelo crime de tráfico; estudou até a $6^{a}$ série).

Com base nas repostas, observa-se que a televisão exerce uma importante função na vida das internas durante o cumprimento da pena, o que vai ao encontro das reflexões de Mcluhan (1964, p. 369), para o qual "A imagem da TV cria uma obsessão com o bem-estar físico". A televisão é tão importante no âmbito do cárcere, que, quando um aparelho dá defeito, a líder da cela faz uma coleta para comprar outro - e quem não tiver dinheiro no momento deverá fazer algum trabalho para pagar a sua cota.

Sobre a dimensão adquirida pela TV no meio social, Bucci e Kehl (2004, p. 33) afirma que "A televisão é um lugar em si [...] a TV como lugar nada mais é que o novo espaço público, ou uma esfera pública expandida". Logo, entender a TV como um espaço público, significa que ela é um lugar onde há integração, multiplicidade de culturas e circulação das representações simbólicas. Dessa forma, a mídia ocupa um lugar de destaque na prisão, porque influencia o pensamento e a atitude das pessoas ajuda a passar o tempo e distrai. Ao realizar visita a um dos blocos do CRF para conhecer a disposição dos aparelhos de TV nas celas, as internas estavam assistindo a um jogo da copa do mundo. $\mathrm{Na}$ ocasião, ao perguntar a importância da TV para elas, todas começaram a falar ao mesmo tempo e as respostas foram unânimes:

Se não tivesse a TV seria um tédio. O número de rebelião seria maior, porque não teria nada pra distrair. Só temos visita de sete em sete dias, então é um meio de informação lá de fora. O que a gente sabe é através da TV, e às vezes das meninas que trabalham lá fora. Mente vazia é oficina do diabo" (Internas do semiaberto, anexo V).

De acordo com Thompsom (2012, p. 58), o uso da tecnologia torna as pessoas capazes de "transcender os limites característicos de uma interação face a face. Ao mesmo tempo, as leva a reordenar as questões de espaço e de tempo dentro da organização social, e usa esta reorganização como meio para atingir seus objetivos". Percebe-se, então, que a TV é um objeto especial e valioso para as mulheres presas. É por meio desta que essas mulheres constroem uma imagem do mundo fora da prisão, situam-se no tempo e no espaço e tentam organizar suas vidas. Para as internas, não é possível uma prisão sem a TV. 


\section{A SOCIABILIDADE NO CÁRCERE}

Das oito interlocutoras que fizeram parte desta pesquisa, cinco têm idade entre 22 a 30 anos, duas entre 31 a 39 anos, e apenas uma tem idade entre 31 a 39 anos. Do total, seis têm escolaridade até o ensino fundamental incompleto, e apenas duas concluíram o ensino médio. Foi verificado ainda que, antes da prisão, as internas não exerciam profissões que demandssem uma formação específica. Antes de ingressarem no Sistema Penitenciário elas realizavam atividades de babá, garçonete, mototaxista, vendedora, autônoma (venda de confecções femininas) e duas declararam que nunca trabalharam antes do cárcere. Todas afirmaram que trabalhavam na informalidade.

Em relação aos crimes cometidos, cinco foram presas pela acusação de crime de tráfico ilícito de entorpecentes, e as outras três foram presas pelo crime de tráfico, associado a outro crime, como latrocínio ${ }^{8}$, tentativa de homicídio e homicídio. No que se refere à reincidência, cinco estão no CRF pela primeira vez e três são reincidentes na prática criminosa. Retomando a questão da televisão, os programas mais assistidos pelas mulheres em situação de cárcere são os noticiários policiais, isto porque se preocupam com a família, que geralmente está envolvida com o tráfico de drogas, bem como para saber sobre as ocorrências no mundo do crime e dos "conhecidos" que irão chegar à prisão. Os jornais do gênero policial veiculados da Região Metropolitana de Belém (RMB) pelos canais de televisão são: "Balanço Geral", transmitido de segunda a sábado, ao meio-dia, no canal da Record; "Barra Pesada" e "Metendo Bronca", ambos veiculados de segunda a sexta-feira, entre meio dia e 14h, no canal RBA, afiliada da Band; e o "Rota Cidadã", programa policial veiculado somente aos sábados, no horário do meio- dia, também no canal da RBA. Girassol e Lirio, assim como outras detentas, acompanham os jornais policiais pela preocupação com a familia:

Aqui assisto mais o Balanço e o Barra para ver quem vai cair aqui, de repente minha filha tá no meio. Quando fui presa, o chefe (do tráfico) deu a droga pra minha filha de 16 anos vender para pagar um advogado pra me tirar daqui, mas pedi muito pra ela parar porque ninguém merece estar aqui nesse lugar. Hoje, sei que não vale a pena (Girassol, 37 anos, acusada pelo crime de tráfico e homicídio; estudou até a $6^{a}$ série).

Assisto a esses jornais porque tenho preocupação com meu filho de 22 anos, que está usando drogas. Meu filho passou no 'Balanço Geral' no ano passado (2013) - ele tinha levado 27 facadas. Armaram uma "casinha" (cilada) pra ele numa briga de bola. Esses jornais também mostram nossa realidade (referindo-se ao crime). (Lírio, 39 anos, acusada pelo crime de tráfico; estudou até a $\sigma^{\mathrm{a}}$ série).

8 Segundo o código penal, trata-se do crime de roubo seguido da morte da vítima. 
Além da preocupação com a família, elas assistem aos noticiários policiais para saber dos amigos e do que acontece no mundo do crime:

Antes de ser presa, assistia mais os jornais da Record e da Band, para saber do mundo do crime. Na cadeia só o que me interessa são esses programas. Assisto o 'Balanço', o 'Barra' para saber quais os colegas que caíram na prisão. Tem colegas que saem daqui e morrem lá fora, aí a gente fica sabendo (Girassol, 37 anos, acusada pelo crime de tráfico e homicídio, estudou até a $6^{\mathrm{a}}$ série).

Thompson (2012) ressalta que a importância atribuída pelos indivíduos aos conteúdos veiculados nos meios de comunicação de massa depende da formação e da condição socioeconômica de cada pessoa nesse processo. Conforme os relatos, as internas assistem aos programas policiais porque de alguma forma representam o seu "mundo", as suas experiências. É o meio pelo qual elas podem saber o que acontece com os seus familiares. Além do quê, a ausência dos filhos e da família é uma das maiores angústias provocadas pela detenção, e que elas irão enfrentar durante o cumprimento da pena (SANTANNA, 2012; MAKKI; SANTOS, 2010; ESPINOZA, 2004). Sem visita, as internas precisam se submeter às regras de sobrevivência na prisão, por meio de favores.

Aquela interna que não tem dinheiro para a coleta da TV irá fazer uma faxina na cela ou lavar a roupa de alguém, geralmente da líder, para pagar a sua cota e ter direito de assistir a programação na televisão. Quando estava no fechado, todo mundo ajudou a colocar a TV pra dentro; eu ajudei a comprar porque lavei duas vezes a roupa de uma interna; foi 10 reais cada lavagem - dei 15 pra TV e fiquei com cinco reais. Como aqui no semiaberto não tenho a minha televisão, eu continuo fazendo esses favores pra poder assistir um pouco de TV com algumas colegas e comprar algumas coisas pra mim (Jasmim, 28 anos, acusada por tráfico de drogas, estudou até a $4^{\mathrm{a}}$ série).

Coelho (2005, p. 79-80) define essa realidade das internas desassistidas pela família como "dupla condição de penúria e de dependência [...], que as administrações prisionais virtualmente nada fazem para eliminar", porque consideram essas relações de dependência como substitutivas da presença do poder público. Para Espinoza (2004, p. 167), “a prisão não passa de uma fotografia da mesma desigualdade retratada no espaço livre". O uso da TV é um foco de conflitos na prisão, pois quem não obedece aos códigos de conduta do cárcere estabelecido pelas próprias internas para a utilização do aparelho é punido.

A Camélia puxou a TV da cela da tomada e disse que ninguém iria assistir mais nada, que as pessoas teriam que aturar ela porque ela foi obrigada a vender a televisão dela pra pagar uma dívida de droga. Agora, ela também 
liga a TV da cela de madrugada para incomodar as demais, por isso que teve briga. Ninguém tem culpa dela ter perdido a TV dela (Amor Crescido, 25 anos, presa por tráfico de drogas, ensino médio completo).

Para Camélia (acusada de tráfico e latrocínio), ter a própria televisão significava não se submeter às regras da TV coletiva, mas sim ligar e desligar o parelho a hora que quisesse, sem ter que "dividir nada com ninguém porque gosta de viver isolada". Por isso, tinha a sua própria TV, que ficava em cima da sua cama. De acordo com Cavalcante Júnior (2004, p. 15), "Os padrões culturais e simbólicos da organização passam a ser reguladores das atividades dos indivíduos, e se configuram em processos de poder e na manutenção da própria organização enquanto tal". No CRF, como em qualquer instituição, há regras que precisam ser cumpridas para a manutenção da ordem e da tolerância, caso contrário os conflitos seriam preponderantes. Contudo, essas regras muitas vezes são infringidas, pela própria peculiaridade do ambiente carcerário.

Nessa pesquisa utilizamos o conceito de cárcere na perspectiva de Goffman (1974, p.17), que corrobora a realidade enfocada, assegurando que "uma disposição básica da sociedade moderna é que o indivíduo tende a dormir, brincar e trabalhar em diferentes lugares, com diferentes co-participantes, sob diferentes autoridades e sem um plano racional geral". No entanto, quando o indivíduo chega a uma prisão, lugar que Goffman (1974) chama de "instituição total", rompe com esse modo de vida e todas as tarefas passam a ser realizadas na "companhia imediata de um grupo relativamente grande de outras pessoas, todas elas tratadas da mesma forma e obrigadas a fazer as mesmas coisas em conjunto", pois passam a conviver em um mesmo espaço, sujeitos às mesmas regras formais e informais, bem como às atividades obrigatórias para atender a um determinado objetivo, sejam determinados pela instituição ou pelas internas, em prol dos seus próprios interesses. Goffmam (1974) entende que esse processo de submissão ocasiona a "mortificação do eu", originado por mudanças nas suas crenças.

Nesse sentido, começam a surgir as formas de poder simbólico ${ }^{9}$ entre as presas, que, por sua vez, dependem dos códigos criados por elas. Esta "sociedade dentro da sociedade" se organiza em torno de lideranças que são comuns ou não em cada cela, pavilhão ou de uma líder gera,l que todos sabem quem é, mas ninguém revela publicamente (CAVALCANTE JÚNIOR, 2009, p. 362).

Assim, para assistir televisão coletivamente é preciso estar atento à liderança dentro da cela, pois quem decide quando ligar ou desligar a TV, a mudança de canal e a programação que o grupo irá assistir é a interna considerada "chefa" ou "líder" da cela ou do bloco, que também lidera os motins, rebeliões e todo tipo

9 Para uma leitura mais aprofundada sobre o poder simbólico, ver Bourdieu (2012). 
de reivindicação. Nesse contexto, a liderança se desenvolve em torno da detenta mais antiga, daquela que tem maior poder aquisitivo para se sustentar na prisão, sem depender de outra interna ou daquela que lidera a modalidade do crime cometido fora do ambiente da prisão.

Tem gente que se sente humilhada porque quer assistir um canal e a dona da TV vai lá e não deixa ou desliga a TV. Tem muita confusão aqui no CRF por causa da televisão. Eu divido a TV com outra, mas a TV é minha, eu que comprei, eu que mando. Só deixo ela assistir alguma coisa quando não tô a fim de assistir o que gosto. Para ligar e desligar, tem que ter autorização da chefa. É a chefa que comanda tudo, até o motim, rebelião, reivindicações (Lírio, 39 anos, acusada pelo crime de tráfico; estudou até a $6^{a}$ série).

Dessa forma, infere-se que as interações entre as internas se dão a partir de uma relação simbólica de legitimar as lideranças dentro do cárcere, e agir conforme as determinações dessa liderança, porque a cultura da prisão assim a produziu. Neste sentido, Thompson (2012) considera que na produção das formas simbólicas os indivíduos se valem dessas relações para realizar ações que possam lhes favorecer no decorrer dos fatos, levando a consequências as mais diversas. Este autor afirma que o poder simbólico "pode provocar reações, liderar respostas de determinado teor, sugerir caminhos e decisões, induzir a crer e descrer, apoiar os negócios do Estado ou sublevar as massas em revolta coletiva" (THOMPSON, 2012, p. 42). Verificamos durante a pesquisa o caso de Margarida, que exerce a liderança na prisão pela sua influência no tráfico de drogas e porque não depende de ninguém para sobreviver no CRF. Portanto, ocupar a posição de Margarida significa negociar com a direção, autorizar ou não uma rebelião e determinar quem irá assistir ou não à televisão, entre outras decisões.

Elas gostam desses programas de crime e eu não gosto. A programação que a maioria gosta é diferente da minha. Só assisto a programação da Globo. Gosto de assistir o 'Jornal Nacional', 'Ana Maria Braga', 'Bom Dia Brasil'. Assisto os jornais policiais só quando tem algo de muito interessante ou é alguma notícia da cidade de Marabá. Procuro me isolar porque o comportamento delas não faz parte do meu eu. Elas se amigam com outras mulheres, e isso eu não aceito. Eu também não me adapto ao linguajar delas, meu nível cultural é diferente (Margarida, 46 anos, acusada pelo crime de tráfico; técnica em administração e contabilidade).

Até aqui, observou-se que Camélia e Margarida não se submetem às regras da TV coletiva, porque preferem sua individualidade, pelo menos nesse aspecto. Atribuímos esse fato ao perfil e história de vida de cada uma, o que está diretamente envolvido com a prática do crime e a escolaridade. 
Outro programa que une as internas em torno da televisão é a novela "Em Família”, veiculada na rede Globo. A história principal da trama é o namoro entre duas mulheres, em que uma delas é casada e deixa o marido para ficar com a outra em prol do amor. Durante a pesquisa, a maioria das interlocutoras revelaram que gostam dessa programação porque retrata a homosexualidade, realidade vivida pelas internas no cárcere.

Sabe, meu marido me fez sofrer muito, por isso, aqui passei a gostar de mulher, a lembrança dele me faz sofrer muito. Sabe, agora que eu gostei mais da novela 'Em Família', porque ela (Giovana Antonelli, protagonista) deixou o marido pra ficar com o amor dela. Todo mundo aqui gosta dessa novela (Rosa Vermelha, 30 anos, acusada pelo crime de tráfico e tentativa de homicídio, estudou até a $\sigma^{\mathrm{a}}$ série).

Verônica Policarpo (s.d.), em pesquisa sobre a percepção do conteúdo de telenovela, explica que mulheres em diferentes situações conjugais, ou seja, com trajetórias familiares distintas, diferenciam-se na forma de ver a telenovela, "em virtude de possuírem diferentes representações e valores sobre a família, os papéis sexuais e a ideia de amor romântico".

A telenovela surge com uma força explicativa renovada. Pela forma como atualiza o mito do amor-romântico e pela forma como é usada pelos indivíduos que a ela assistem para (re) interpretar, compreender e narrar a sua própria vida. A telenovela surge assim como um interlocutor privilegiado para estes telespectadores, que se sentem (paradoxalmente) através dela, mais do que nunca protagonistas de um drama maior: o da sua própria Vida (POLICARPO, s.d., p. 15).

Em relação às atividades de rotina no cárcere feminino, observamos que o uso da TV ocorre com mais frequência nos horários dos noticiários policiais e das novelas. Pela manhã, elas assistem às notícias policiais do jornal "Fala Pará", às 7 h, no canal da Record. Em seguida realizam suas tarefas, que geralmente são: lavar roupa, fazer a faxina na cela ou realizar algum trabalho manual dentro do CRF, como crochê, manicure, artesanato; ou procuram os serviços das assistências disponíveis, como médico, dentista, aulas, psicóloga e assistente social. Na hora do almoço elas retornam e assistem aos jornais policiais que são veiculados ao meio dia, e da mesma forma ocorre na parte da tarde e da noite, quando são veiculados novamente os jornais e as novelas. Isso nos permitiu constatar que o tempo dedicado à realização das atividades gira em torno da televisão.

Diante desse contexto, destaca-se o que Simmel (1983) define como sociabilidade. Para o autor, a sociabilidade é vista como o sentimento de prazer por estar se relacionando com pessoas que escolhemos. É a satisfação de integrar 
um grupo com o objetivo exclusivo de gozar dessa relação. Simmel (1983) afirma que para haver a sociabilidade as diferenças devem ser postas em segundo plano. Se essas diferenças forem muitas, a possibilidade de existir sociabilidade diminui. A partir dos conceitos de Simmel (1983), entendemos que a sociabilidade no cárcere é limitada, uma vez que o prazer de se relacionar é momentâneo. As mulheres em situação de cárcere encontram-se em uma "instituição total" (GOFFMAN, 1974), que busca moldar o indivíduo por meio de regras, forçandolhes a conviver com os que lá estão. Logo, elas não têm a chance de realizar suas atividades em outros locais, com pessoas que realmente lhes façam felizes. Sem a chance de escolha, agrupam-se por aquilo que têm em comum.

Portanto, a sociabilidade no cárcere não é absoluta - ela é momentânea. Em geral, os momentos de sociabilidade ocorrem quando as internas se reúnem em torno da TV para assistir aos programas policiais, para saber se alguém da família, amigos ou ex-internas foram presos, como também à novela "Em Família", ao programa "Pará Show", aos jogos de futebol. Apreende-se, então, que a TV aproxima as mulheres num local de tantos conflitos e diferenças, porque essas programações propiciam momentos em que elas abstraem suas "qualidades objetivas e subjetivas" para que possam se relacionar umas com as outras. "Na sociabilidade não entram o que as personalidades possuem em termos de significações objetivas; [...] riqueza, posição social, erudição, fama, capacidades excepcionais e méritos individuais não desempenham qualquer papel na sociabilidade" (SIMMEL, 2006, p. 67). Então, nas ocasiões em que se reúnem em torno da TV, as mulheres conseguem "jogar o jogo da sociabilidade" (SIMMEL, 1983).

\section{INTERAÇÃO E CONFLITO PELO USO DA TV}

Como visto anteriormente, o fato de as internas assistirem assiduamente aos jornais e programas policiais vêm gerando hostilidades no âmbito da instituição carcerária, à medida que acompanham esses noticiários, podem obter informações sobre o destino de seus familiares envolvidos no crime e das novas detentas que chegarão ao CRF, como também sobre os seus desafetos. Esta situação tem causado conflitos dentro do cárcere, visto que através dessas notícias ficam sabendo se alguma interna recém-chegada ao CRF cometeu um crime repudiado pelas "regras da prisão". Caso isso seja confirmado, esta interna ficará isolada e não poderá participar de nenhuma atividade de ressocialização, sob o risco de sofrer violência ou até mesmo de morte.

Na convivência diária das mulheres em situação de cárcere evidencia-se o que Colares e Chies (2010) chamam de "prisão dentro da prisão", ou seja, as 
internas que são excluídas da convivência com as outras presas porque cometeram crimes que não são aceitos pelas regras informais do cárcere, como, por exemplo: mãe que matou o filho, filha que assassinou a mãe ou avó, maus-tratos a crianças e idosos, entre outros.

A consequência da medida punitiva de isolamento, que aqui decidimos nomear de "dupla exclusão social", em que utilizam duas celas chamadas de "seguro", localizadas no anexo ${ }^{10} \mathrm{~V}$ do regime semiaberto. As celas receberam este nome porque à época da pesquisa abrigavam sete internas que precisam ficar isoladas das outras. Essas mulheres são chamadas de "brindes" ${ }^{11}$ ", e só podem sair da cela para o banho de sol, mesmo assim devem sempre ficar próximas às agentes penitenciárias, por questões de segurança, visto que se essas "brindes" forem inseridas no bloco carcerário sofrerão maus tratos, isso pode levar até a sua morte. Neste caso, a prisão é vista como um sistema que propicia a violência porque gera exclusão daquelas mulheres que já se encontram excluídas da sociedade. Dentre os relatos, os mais expressivos foram de duas interlocutoras. Vejamos:

A TV serve pra gente ver os crimes que acontecem lá fora. Se for alguém que matou a mãe ou o filho, a direção já sabe tem que ir direto para a cela dos brindes. Se vier pro bloco, vai apanhar muito. Eu já presenciei muitas porradas nos brindes e já participei também. Tem uma aí que matou a mãe. O que você acha? Se ela matou a mãe, imagina o que ela pode fazer comigo ou com qualquer outra quando tiver dormindo? Tem outra coisa: aqui a gente fica muito atribulada, preocupada com a família, com os filhos, com o processo, que ninguém dá informação. Então, na hora da raiva a gente vai descontar nos brindes. Então é melhor ficar separada (Lírio, 39 anos, acusada pelo crime de tráfico; estudou até a $6^{\text {a }}$ série).

A maioria assiste o "Balanço Geral" para saber quem vem pra cá, com quanto $^{12}$ que foi pego. Se chegar alguém aqui que fez alguma maldade que a gente não aceita, não entra no bloco, vai pros brindes e jamais pode circular. Minha mulher pegou uma e fez muita maldade, cortou o cabelo dela igual de homem e bateu muito nela. A gente não perdoa, regra é regra. Se eu pegar eu corto a cara dela (Alecrim, 29 anos, presa por tráfico de drogas, estudou até a $6^{\text {a }}$ série).

Thompson (2012) alerta que os meios de comunicação, ao divulgar imagens e informações de fatos ocorridos em lugares muito além de seus ambientes sociais imediatos, "podem estimular ou intensificar formas de ação coletiva difíceis de

10 Uma edificação construída no formato retangular, dividida em várias partes, formando quartos que são usados como celas. Essa construção é separada dos pavilhões onde ficam as internas sob custódia no regime fechado.

11 São as internas que não podem circular no CRF porque podem sofrer violência, ou pelo crime que cometeram, ou porque tem desafetos no CRF.

12 Refere-se à quantidade de droga. 
controlar com os mecanismos de poder estabelecidos" (Ibid., p. 156). Note-se que há ou não a aceitação dos crimes pelas detentas. Aquelas que se envolvem com o tráfico, assalto ou latrocínio são aceitas e respeitadas no cárcere. Já as que cometem crimes cujas vítimas são seus próprios familiares são repudiadas. Essas internas agem como se não estivessem sob as mesmas leis e normas.

$\mathrm{Na}$ fala da diretora do CRF pode-se verificar que ela é contra o uso irrestrito da televisão, porque as internas que são consideradas "brindes" já chegam à prisão sem chances de ser inseridas nos projetos de reinserção social exigidos pela (LEP). Contudo, não há uma norma estabelecida por parte do gestor da Susipe para regularizar e orientar o uso dos aparelhos de TV. A diretora defende que o controle do uso da televisão deveria ser formalizado por meio de uma portaria ou outro documento, porque a LEP assegura que o diretor da unidade pode suspender ou restringir o uso dos equipamentos caso prejudique os bons costumes, o que não violaria o direito à informação, porque se estaria preservando um bem maior que é a vida.

Esses programas policiais trazem o culto da violência para dentro do cárcere. A presa que já chega na prisão hostilizada - não pode tomar banho de sol, não pode estudar porque as outras querem violentá-la, ou seja, essa presa não pode ser inserida em nenhum projeto. A presa fica isolada, como inserir se ela tem que ficar isolada? A cadeia não tem estrutura para isso (Diretora do CRF).

No entanto, como a TV é um instrumento de poder (COSTA, 2004), poderia ser perigoso o diretor da unidade prisional restringir o uso do equipamento sem antes passar por uma discussão mais ampla com os profissionais que atuam na instituição, embora seja autorizado por lei. Considerando esse contexto, pondera-se que a TV na prisão tornou-se um panóptico invertido, ou seja, não é mais somente a prisão que está sob um olhar vigilante com o intuito de disciplinar os corpos (FOUCAULT, 2011). Agora são várias mulheres "vigiando" a televisão e observando quem entra e quem sai do cárcere, para então decidirem sobre a punição ou não daquelas cujas práticas criminosas não são aceitas.

Pelos valores estabelecidos na prisão, as internas também exercem o poder de punir, à medida que excluem, ameaçam ou violentam aquelas com as quais não se identificam em função dos crimes, embora legalmente seja uma atribuição exclusiva do Estado. Neste sentido, a gestão da unidade permite essa "estrutura informal de poder para auxiliar a manutenção da ordem social” (DIAS, 2014, p. 119). Por conseguinte, as "brindes" tornam-se vítimas do próprio Sistema Penitenciário, que as submete a situações de violência física e simbólica, por vezes, sem a devida consciência e reflexão sobre esta prática. 
As práticas punitivas reforçam as redes de poder que perpassam as relações entre os presos e, nesse sentido, a punição deixa de operar no campo do disciplinamento e se insere, antes, no campo do controle social. Controle social cujo objetivo passa a ser a manutenção do funcionamento da dinâmica prisional - com todas as assimetrias, formas de dominação, violência física e simbólica que lhe constitui - e, portanto, com a permanência de uma ordem social marcada por múltiplas formas de sujeição (DIAS, 2014, p. 125).

Assim, se já é difícil a instituição cumprir a sua função ressocializadora, seja pelas instalações insalubres, seja pela precariedade no atendimento dos serviços assistenciais verificadas durante pesquisa, imagine para aquelas que nem mesmo têm a oportunidade de buscar esses serviços. Daí porque se torna uma contradição o discurso de reinserção social no âmbito do Sistema Penitenciário.

Em contraponto ao clima de hostilidade causado pelos noticiários policiais nesta unidade prisional, há o programa de entretenimento chamado "Pará Show", que é veiculado aos sábados, às 19h, na TV Metropolitana, canal 14. Este programa é o preferido das internas durante os finais de semana, pois mostra as festas de aparelhagem, as pessoas bebendo cerveja, dançando as suas músicas preferidas, que são o tecnobrega ${ }^{13}$ e o funk ${ }^{14}$. Durante a programação, as internas veem os amigos, os familiares, os ex-namorados e maridos, muitas vezes com novas namoradas. Trata-se uma forma de se aproximar e matar as saudades das festas que frequentavam antes da prisão. Durante as visitas da primeira autora ao CRF, foi possível conversar com outras internas enquanto aguardava uma das interlocutoras. Apesar não participarem oficialmente da pesquisa, elas quiseram falar sobre o programa que mais gostavam. Na ocasião, foi citado o "Pará Show" como o programa favorito aos finais de semana.

Na hora do "Pará Show", as meninas dançam, gritam, cantam, todas as TVs ficam ligadas em volume alto. Nessa hora não há reclamação. Todo mundo se une. A gente gosta do "Pará Show" por causa das músicas do tecnobrega, das festas que aparecem. A gente identifica os conhecidos e depois comenta com as outras, tu sabe quem tava no "Pará Show", fulano, ciclano" (Internas do CRF).

O "Pará Show" faz com que elas se anestesiem do intramuros e se transportem para o extramuros. É uma alegria momentânea, elas extravasam. Já os jornais policiais são uma preocupação com a família" (Agente penitenciária, há 6 anos trabalhando no CRF).

13 O tecnobrega é a fusão do tradicional ritmo do brega paraense com a música eletrônica, tendo a tecnologia como um elemento fundamental. O novo gênero musical deriva de ritmos como o carimbó, siriá, lundum, calypso e guitarradas. O tecnobrega surgiu no Pará nos anos 2000.

14 O Funk origina-se na música negra norte-americana surgida na década de 1960, a partir da soul music, com influência do rock e da música psicodélica. As características desse estilo musical são o ritmo sincopado, a densa linha de baixo, uma seção de metais forte e rítmica, além de uma batida marcante e dançante. 
De acordo com Canclini (2002), os significados dos conteúdos veiculados nos meios de comunicação para cada indivíduo, irá depender de sua bagagem cultural, da sua trajetória de vida, pois os programas televisivos são representações da vida cotidiana a partir de uma imagem construída. Logo, a TV cria novas formas de ação e interação e novos tipos de relacionamento social.

Para Thompson (2012, p. 119), com os meios de comunicação "a interação se dissocia do ambiente físico, de tal maneira que os indivíduos podem interagir uns com os outros ainda que não partilhem do mesmo ambiente espaço temporal" (Ibid., p. 119). Entre esses tipos de interação, o autor destaca um que reflete o uso da TV no contexto do cárcere feminino. Trata-se da "quaseinteração mediada", que é aquela em os indivíduos se ligam uns aos outros num processo de comunicação e intercâmbio simbólico.

Outro conflito que gira em torno da televisão é a situação das internas que trabalham e das que não trabalham. No regime semiaberto há internas que trabalham no próprio CRF ou fora dele, por meio de convênios firmados pela Susipe com outros órgãos públicos e empresas privadas; e há aquelas que não exercem nenhuma atividade. Estas últimas gostam de assistir a TV até de madrugada e com o volume alto. Já as que trabalham preferem que o aparelho seja desligado mais cedo.

Por isso, à noite, por causa da TV coletiva, iniciam-se as brigas, discussões e conflitos, porque as internas que não precisam acordar cedo para trabalhar ficam conversando e assistindo televisão até de madrugada. Segundo as interlocutoras, às vezes é preciso a líder ou outra interna que seja respeitada na cela interferir para que a situação seja resolvida naquele momento.

À noite, quando as colegas chegam do trabalho tem confusão, porque umas querem ficar assistindo até tarde, e as que trabalham querem que desliguem. A gente gosta de deixar a TV ligada pra fazer algum barulho, pra animar, porque fica muito silêncio à noite (Lirio, 39 anos, acusada pelo crime de tráfico, estudou até a $\sigma^{a}$ série).

Dessa forma, muitas internas do regime semiaberto que trabalham fora do CRF têm sua TV individual. Isto porque elas precisam dormir cedo para trabalharem cedo no dia seguinte. No entanto, não pude entrevistá-las porque não são alvo desta pesquisa, conforme mencionado na metodologia. Frente aos conflitos e interações aqui apresentados que cercam a sociabilidade das internas na prisão feminina, Cavalcante Junior (2009), discorre que o sistema penitenciário é constituído de espaços sociais ligados ao poder. Esses espaços são descentralizados e formados por pessoas que produzem e reproduzem dentro da instituição campos simbólicos de poder, discursos e linguagens codificadas 
de ordenamento social. Diante do exposto, ressignificaremos a forma como Goffman (1974, p. 22) define o conceito de cárcere. Para ele, o cárcere é uma insituição fechada, simbolizada pela barreira que impede o contato com o mundo externo e por proibições à saída das pessoas que lá se encontram. Porém, diante do acesso das internas à TV, e conforme os resultados verificados, o CRF não é mais uma instituição totalmente fechada. As mulheres em situação de cárcere têm contato com o mundo, porque a televisão lhes proporciona isso. Contato esse que faz com que elas relembrem e acompanhem momentos da vida, e até mesmo decidam sobre qual atitude tomar diante de algumas situações.

\section{CONCLUSÕES}

Diante do resultado da pesquisa, pode-se comprovar a hipótese definida no início deste trabalho, de que a televisão é considerada pelas internas um instrumento essencial para o cumprimento da pena porque as mantêm informadas sobre o que está acontecendo no mundo, ajuda a passar o tempo e diminui o sofrimento proveniente da privação da liberdade. Torna-se, dessa forma, um instrumento de poder dentro do cárcere, à medida que firmam contato com mundo exterior, rompendo a barreira entre o ambiente externo e a prisão, o que, segundo Goffman (1974), caracteriza uma "instituição total".

As mulheres em situação de cárcere assimilam os conteúdos da TV em um ambiente de reclusão, com regras e normas estabelecidas, que, em tese, devem ser seguidas. Portanto, a partir do conceito de mídia, entende-se, que a televisão rompe barreiras, não isolando o indivíduo, mas possibilitando o contato deste com o mundo externo, uma vez que a programação veiculada traz experiências, sentimentos e uma sociabilidade que envolve prazer, poder e conflitos.

Os programas preferidos pelas mulheres presas são os jornais policiais, pela preocupação com a família, que geralmente encontra-se envolvida no tráfico; e o programa "Pará Show", visto que mostra as festas noturnas que elas frequentavam antes da prisão, além de ser uma oportunidade para ver seus familiares, amigos e ex-companheiros. Outra preferência é a novela "Em Família", porque trata da questão da homosexualidade, realidade comum no presídio feminino.

Do ponto de vista da sociabilidade proporcionada pelo uso da TV, os momentos de interações sociais limitam-se aos horários em que se reúnem para assistir ao programa "Pará Show", à novela "Em Família" e aos jornais ou programas policiais. Estes últimos trazem problemas de hostilidade para a prisão, de forma a tornar o CRF uma dupla prisão, situação que não pode ser ignorada pelas autoridades que gerenciam o sistema carcerário. Portanto, uma das soluções 
possíveis para minimizar esse efeito, seria lançar um olhar diferenciado para o uso da televisão naquela unidade prisional exclusivamente feminina.

A utilização da TV deve ser aliada do processo de reinserção social e não uma barreira para alcançar este objetivo. O que se deve considerar na prisão, além dos conflitos, é a garantia prevista pela LEP: de reinserir o indivíduo na sociedade. Logo, se bem utilizada, a TV pode contribuir positivamente nesse processo.

\section{REFERÊNCIAS}

BRASIL, Lei 7.210 (Lei de Execução Penal), Publicada no Diário Oficial da União em 13 de julho de 1984 .

BOURDIEU, P. O Poder Simbólico. Rio de Janeiro: Difel, 2012

BUCCI, Eugênio; KEHL, Maria Rita. Videologias. São Paulo: Boitempo, 2004.

CANCLINI, N. G. Consumidores e cidadãos. Rio de Janeiro: UFRJ, 2002.]

CAVALCANTE JÚNIOR, Amadeu de Farias. Sociedade do Cárcere: A Inversão de uma Ordem e a Intervenção dos Dispositivos de Poder-Saber numa Instituição Penal da Região Metropolitana de Belém. 2004. Dissertação (Mestrado em Sociologia). Belém/ Pará: Universidade Federal do Pará.

Estado, Punição e Religião: Pentecostais e Neopentecostais entre a secularização e dessecularização da ressocialização no Cárcere. 2009. Tese (Doutorado em Sociologia). Belém/Pará: Universidade Federal do Pará.

COELHO, Edmundo Campos. A Oficina do Diabo. Rio de Janeiro: Record, 2005.

COLARES, Leni Beatriz Correia; CHIES, Luiz Antônio Bogo. Mulheres nas So(m) bras: Invisibilidade, Reciclagemm e Dominação Viril em Presídios Masculinamente mistos. In: Revista Feminista, v.18, n²/2010. Florianópolis: UFSC, 2009.

COSTA, Alda Cristina Silva. A Violência como Espetáculo: Um Debate em Torno do Programa Metendo Bronca. 2004. 189 f. Dissertação (Mestrado em Sociologia), Instituto de Filosofia e Ciências Humanas, Universidade Federal do Pará, Belém, 2004.

DIAS, Camila Nunes. Disciplina, Controle Social e Punição: O Entrecruzamento das Redes de Poder no Espaço Prisional. In: Revista Brasileira de Ciências Sociais, v.29, n. 85. São Paulo, 2014.

ESPINOZA, Olga. A Mulher Encarcerada em Face do Poder Punitivo. São Paulo: IBCCrim, 2004.

FOUCAULT, Michel. Microfísica do Poder. 25. ed. São Paulo: Graal, 2012.

Vigiar e Punir: Nascimento da prisão. Tradução: Raquel Ramalhete. 39. ed. Petrópolis: RJ, Vozes, 2011. 
GIL, Antônio Carlos. Métodos e Técnicas de Pesquisa Social. 6. ed. São Paulo: Atlas, 2012.

GOFFMAN, Evring. Manicômios Prisões e Conventos. São Paulo: Perspectiva, 1974.

LAKATOS, Eva Maria; MARCONI, Maria de Andrade. Metodologia Científica. 6. ed. São Paulo: Atlas, 2011.

MAKKI, Salma Hussein; SANTOS, Marcelo Loeblein dos. Gênero e Criminalidade: Um Olhar sobre a Mulher Encarcerada no Brasil. Âmbito Jurídico, Rio Grande, XII, n. 78, jul 2010. Disponível em http//www.ambito-juridico.com.br. Acesso em outubro de 2014.

MCLUHAN. Marshall. Os Meios de Comunicação Como Extensões do Homem. São Paulo: Cultrix, 1964.

PARÁ. Superintendência do Sistema Penitenciário do Pará. Relatório Susipe em Números. Disponível em: http://www.susipe.pa.gov.br/sites/default/ files /SETEMBRO \%202014\%20-\%20RELATORIO\%20SUSIPE \%20EM $\% 20$ NUMEROS_1.pdf

POLICARPO, Verônica Melo. As mulheres e a telenovela: um estudo sobre a recepção de Terra Nostra (s/d). Revista Novos Media e Cidadania, $n^{\circ}$ 3. Disponível em: $<$ http://www.labcom.ubi.pt/agoranet/03/policarpo-veronica-mulheres-e-telenovelaterra-nostra.pdf>. Acesso em: 28 janeiro de 2014.

SANTANA, Ana Paula Palheta. A Casa Dos Días: A Vida no Cárcere Feminino. 2012. Tese (Doutorado em Ciências Sociais). Belém/Pará: Universidade Federal do Pará.

SIMMEL, G. Simmel: Questões Fundamentais da Sociologia: Indivíduo e Sociedade. Rio de Janeiro: Zahar, 2006.

Sociabilidade: Um exemplo de Sociologia Pura. In: MORAES, F. Evaristo de. Sociologia. São Paulo: Ática, 1983.

THOMPSON, Augusto. A Questão Penitenciária. 5. ed. Rio de Janeiro: Forense, 2002. THOMPSON, John B. A mídia e a modernidade: uma teoria social da mídia. Petrópolis, RJ: Vozes, 2012. 